\title{
Brazilian Scientific Research about Acupuncture in Dentistry: Bibliometric Analysis of the Papers Presented at SBPqO Meetings
}

\section{A Pesquisa Científica Brasileira Sobre Acupuntura na Odontologia: Análise Bibliométrica dos Trabalhos Apresentados nas Reuniões da SBPqO}

\author{
a State University of Paraíba, Graduate Program in Dentistry. PB, Brazil. \\ *E-mail: mhcvcatao@gmail.com \\ Recebido em: 26/04/2019 Aprovado em: 03/07/2019
}

José de Alencar Fernandes Netoa; Pettely Thaise de Souza Santos Palmeira ${ }^{a}$; Jhonatan Thiago Lacerda-Santos Ana Luzia Araújo Batista ${ }^{a}$; Thamyres Maria Silva Simõesa; Maria Helena Chaves de Vasconcelos Catão*a

\begin{abstract}
The aim of this study was to investigate the Brazilian scientific production about acupuncture in dentistry, outlining the profile of the works about the subject presented at the Meetings of the Brazilian Society of Dental Research (SBPqO). It was a cross-sectional study, with a quantitative approach, based on secondary data. An analysis of all abstracts presented in the last ten SBPqO Meetings (2009-2018) published in the annals of the event was carried out. For the research the location of the term "acupuntura" or "acupuncture" among the abstracts was realized and the following information was collected: type of institution that carried out the research (public or private), Brazilian region where it was realized, area or specialty of dentistry and whether it involved humans or animals. Of the 26,514 dental research abstracts published in the annals, only 27 papers were experimental studies or systematic reviews about the subject. Of the total, $23(85.2 \%)$ were developed in public institutions, $15(55.6 \%)$ did not receive financial support $20(74.1 \%)$ were carried out in humans and $13(48.2 \%)$ were developed in the Southeast region. Regarding the dental specialty, the majority (70.4\%) investigated acupuncture in "Temporomandibular Dysfunction and Orofacial Pain". Therefore, it can be concluded that few acupuncture studies in dentistry have been developed in the last ten years in Brazil, according to the papers presented at the SBPqO Meetings. Thus, it is suggested that research on the subject be carried out and widely disseminated between the academic and professional milieu.
\end{abstract}

Keywords: Acupuncture Therapy. Dental Research. Complementary Therapies.

\section{Resumo}

O objetivo desse estudo foi investigar a produção cientifica brasileira sobre a acupuntura na odontologia, traçando o perfil dos trabalhos sobre a temática apresentados nas Reuniões da Sociedade Brasileira de Pesquisa Odontológica (SBPqO). Tratou-se de um estudo transversal, com abordagem quantitativa, a partir de dados secundários. Realizou-se uma análise de todos os resumos apresentados nas últimas dez Reuniões da SBPqO (2009-2018) publicados nos anais do evento. Para pesquisa procedeu-se a localização do termo "acupuntura" ou "acupuncture" entre os resumos e foram colhidas as seguintes informações: tipo de instituição que realizou a pesquisa (pública ou privada), região brasileira onde foi realizada, recebimento de auxílio financeiro, área ou especialidade da odontologia e se envolvia humanos ou animais. Dos 26.514 resumos de pesquisa odontológica publicados em anais, apenas 27 trabalhos tratavam de estudos experimentais ou revisões sistemáticas sobre a temática. Do total, 23 (85,2\%) foram desenvolvidos em instituições públicas, 15 (55,6\%) não receberam auxílio financeiro, 20 (74,1\%) foram realizados em humanos e 13 (48,2\%) desenvolvidos na região Sudeste do Brasil. Com relação a especialidade odontológica, a maioria (70,4\%) pesquisou sobre a acupuntura na "Disfunção Temporomandibular e Dor Orofacial”. Os achados do presente estudo indicam que poucas pesquisas abordando a acupuntura na odontologia foram desenvolvidas nos últimos dez anos no Brasil, de acordo com os trabalhos apresentados nas Reuniões da SBPqO. Diante disso, sugere-se que pesquisas sobre o tema sejam realizadas e amplamente divulgadas entre o meio acadêmico e profissionais.

Palavras-chave: Terapia por Acupuntura. Pesquisa em Odontologia. Terapias Complementares.

\section{Introduction}

In the year 2015, the Federal Council of Dentistry (CFO), by means of Resolution CFO-160/2015 ${ }^{1}$, recognized acupuncture as a dentistry specialty, determining that the therapy consists of the application of the basic concepts of Traditional Chinese Medicine (TCM) as a system of knowledge, applying it as a method for the treatment, prevention and/or maintenance of general health status of the dentistry patient, whenever there are clinical circumstances in which there is the participation of the stomatognathic system structures, respecting the limits of the dental surgeon.

Acupuncture has a long history and has proved to be an effective treatment modality in the field of TCM. Surveys were conducted and there was a gradual acceptance of its therapeutic effects, although they are not fully understood yet. The scientific evidence of its role in the management of pain is strong, although wider studies and with the best experimental designs should be carried out to verify their application in other areas ${ }^{2}$.

Among the various clinical indications of acupuncture in dentistry are: treatment of temporomandibular disorders ${ }^{3-5}$, xerostomia and salivary hypoflow ${ }^{6,7}$, control of pain ${ }^{8,9}$, paresthesia $^{10,11}$, syndrome of oral burning ${ }^{12}$ and control of predental care anxiety ${ }^{13,14}$.

The population has increasingly sought by alternative treatments, and among them, the acupuncture. This ancient Chinese technique has been spreading increasingly in the western world and scientific studies have been carried out in all areas, in an attempt to prove or optimize its efficiency ${ }^{8}$. 
Although in recent years, the interest for acupuncture in dentistry has increased ${ }^{15.16}$, at least in part, due to the published results of its effectiveness, the literature is not extensive and results vary considerably: from no effect to significant improvement ${ }^{8,17,18}$. Controlled studies published on the effects of acupuncture in dentistry are still relatively few, but those that meet pre-defined methodological criteria are reviewed to assess whether acupuncture is effective in this field ${ }^{16}$.

Therefore, the aim of this study was to investigate the Brazilian scientific production about acupuncture in dentistry, outlining the profile of the works about the subject presented at the Meetings of the Brazilian Society of Dental Research (SBPqO).

\section{Material and Methods}

It was a cross-sectional study, with a quantitative approach, based on secondary data. An analysis of all abstracts presented in the last ten SBPqO Meetings (2009-2018) published in the annals of the event was carried out, available through its website. It was opted for the work of the Meetings of SBPqO, because it is the scientific event that gathers research in dentistry in Brazil the most, considered a congress reference for researchers across the country.

To search the work, it was proceeded to the location of the term "acupunctura" or "acupuncture" among the abstracts. The search tool "Find in Page" of Microsoft Edge 42.17134.1.0, where the files of proceedings were opened, ensured that the terms were identified, even though they were separated by hyphen. Thus, all abstracts which contained in its title or text one of the two terms could be identified for posterior analysis.

All the jobs that met the following inclusion criteria were included: summaries of experimental research or systematic reviews that clearly addressed the acupuncture in one of the areas of dentistry, developed by an educational institution, and published in the annals from 2009 to 2018, in Portuguese or English. All categories of the annals were assessed, and all data used in this study are of public access.

In abstracts that met the inclusion criteria, the following information was collected: type of institution (public or private), Brazilian region where the research was carried out, granting or not of financial aid, a specialty of dentistry and if research involving humans/animals or whether this was a systematic review. The data were tabulated and analyzed with the support of the software IBM SPSS Statistics version 20.0 (IBM Corp., Armonk, NY, USA).

\section{Results and Discussion}

Of the 26,514 dental research abstracts published in the annals, only 35 contained the terms in question. After analysis, 27 studies were included in the study, because they are experimental studies or systematic reviews about the theme. The abstracts found in literature reviews, bibliometric studies or those who did not deal with research on acupuncture in some area of dentistry, but that only cited the terms in its structure, were excluded $(n=8)$ (Table 1).

Table 1 - Number of published abstracts, found, excluded, selected and the ratio of the number of abstracts about acupuncture and total summaries, according to year of meetings of SBPqO

\begin{tabular}{|c|c|c|c|c|c|}
\hline Meeting - Year & $\begin{array}{c}\text { Published } \\
\text { Abstracts }\end{array}$ & $\begin{array}{c}\text { Abstracts } \\
\text { found with } \\
\text { "acupuntura" } \\
\text { or } \\
\text { “acupuncture" }\end{array}$ & $\begin{array}{c}\text { Excluded } \\
\text { Abstracts }\end{array}$ & $\begin{array}{c}\text { Selected } \\
\text { Abstracts }\end{array}$ & $\begin{array}{c}\text { Proportion of } \\
\text { abstracts on } \\
\text { acupuncture/ } \\
\text { Total abstracts }\end{array}$ \\
\hline 26th - 2009 & 2,648 & 4 & 0 & 4 & $1 / 662$ \\
\hline 27th - 2010 & 2,962 & 3 & 0 & 3 & $1 / 987.3$ \\
\hline 28th - 2011 & 2,873 & 4 & 3 & 1 & $1 / 2,873$ \\
\hline 29th - 2012 & 16 & 0 & 0 & 0 & $0 / 16$ \\
\hline 30th - 2013 & 2,804 & 2 & 0 & 2 & $1 / 1,402$ \\
\hline 31st - 2014 & 2,752 & 4 & 2 & 2 & $1 / 1,376$ \\
\hline 32nd - 2015 & 2,926 & 3 & 1 & 2 & $1 / 1,463$ \\
\hline 33rd - 2016 & 3,207 & 6 & 1 & 5 & $1 / 641.4$ \\
\hline 34th - 2017 & 3,125 & 6 & 1 & 5 & $1 / 625$ \\
\hline 35th - 2018 & 3,201 & 3 & 0 & 3 & $1 / 1,067$ \\
\hline Total & $\mathbf{2 6 , 5 1 4}$ & $\mathbf{3 5}$ & $\mathbf{8}$ & $\mathbf{2 7}$ & $\mathbf{1 / 9 8 2}$ \\
\hline
\end{tabular}

Source: Data collected by the research, using the annals of meetings of SBPqO.

Of the total, $23(85.2 \%)$ were developed in public institutions, $15(55.6 \%)$ did not receive financial support $20(74.1 \%)$ were carried out in humans and $13(48.2 \%)$ were developed in the
Southeast region. Regarding the dental specialty, $70.4 \%$ of the papers were about acupuncture in "Temporomandibular Dysfunction and Orofacial Pain" (Chart 2). 
Table 2 - Distribution of works that deal with acupuncture according to the nature of the institution, receiving financial aid, regions, dental specialty and type of study

\begin{tabular}{|c|c|c|}
\hline Variable & $\mathbf{N}$ & $\%$ \\
\hline \multicolumn{3}{|l|}{ Institution } \\
\hline Public & 23 & 85.2 \\
\hline Private & 04 & 14.8 \\
\hline \multicolumn{3}{|l|}{ Financial support } \\
\hline Yes & 12 & 44.4 \\
\hline No & 15 & 55.6 \\
\hline \multicolumn{3}{|l|}{ Region } \\
\hline Midwest & 03 & 11.1 \\
\hline Northeast & 08 & 29.6 \\
\hline North & 00 & 0 \\
\hline Southeast & 13 & 48.2 \\
\hline South & 03 & 11.1 \\
\hline \multicolumn{3}{|l|}{ Areas/Dental Specialties } \\
\hline Surgery and Bucco-Maxillo-Facial Traumatology & 02 & 7.4 \\
\hline Temporomandibular dysfunction and Orofacial Pain & 19 & 70.4 \\
\hline Endodontics & 02 & 7.4 \\
\hline Stomatology & 01 & 3.7 \\
\hline Periodontics & 03 & 11.1 \\
\hline \multicolumn{3}{|l|}{ Type } \\
\hline Humans & 20 & 74.1 \\
\hline Animals & 06 & 22.2 \\
\hline Systematic review with meta-analysis & 01 & 3.7 \\
\hline Total & 27 & $100 \%$ \\
\hline
\end{tabular}

Source: Research Data.

With the growing acceptance of alternative medicine in the west, acupuncture is quickly becoming a more popular practice. Today, more people are choosing acupuncture to treat body pains, relieve stress or promote the general health. In postoperative pain control or in the management of temporomandibular dysfunction and facial pain, it became a useful alternative to conventional therapeutic arsenal of the dentist $\mathrm{t}^{16}$.

However, acupuncture can be used to manage many disorders in dentistry, also providing a new hope for patients who cannot be treated with conventional treatment modalities. Some of the conditions for which acupuncture can be used effectively include: dental pain, temporomandibular disorder, anxiety, pain or chronic muscle spasm, atypical facial pain, headache, xerostomia, paresthesia and anesthesia of oral structures ${ }^{18}$.

Thayer ${ }^{15}$ points out that acupuncture plays an important role in improving the quality of care that can be provided to dental patients, particularly around the management of the vomiting reflex and the treatment of temporomandibular disorders.

Vianna et al. ${ }^{19}$ also underline that the acupuncture, used correctly, respecting its limitations, following the recommendations and practiced by trained professionals, tends to bring great benefits also to the dentist, optimizing its working time in the office.

This study showed the small number of Brazilian research that studied the relationship between acupuncture and the dentistry in the country. According to Wong ${ }^{2}$, although the recognition and application of acupuncture in the medical field have progressed considerably over the last ten years, its development in the dental area is currently at its initial stage and more clinical papers on its possible applications in dentistry can be performed. After its efficacy having been sufficiently evaluated, acupuncture can be implemented as one of the modalities of treatment available for dental patients in a near future.

Based on Resolution CFO- $160 / 2015^{1}$, the specialist in acupuncture must act in health promotion based on scientific conviction, citizenship, ethics and humanization. In addition, it is possible to work in development, participation and the application of research and/or other forms of knowledge production, aiming the qualification and professional practice based on assumptions of Traditional Chinese Medicine, in the field of dentistry.

It must be considered that in Brazil, until the present date, there are 395 specialists in acupuncture, equivalent to only $0.3 \%$ of the total number of dental surgeons with specialty dental care ${ }^{20}$. Since only in 2015 the acupuncture was recognized by the CFO as a specialty dental care, this fact may explain the small number of studies on the theme in the last ten years.

More than half of the studies $(55.6 \%)$ stated that they did not receive financial aid for the development of the research. Although not all papers require a significant amount to be developed, in most cases, a financial support is essential for the construction and implementation of good studies, since it contributes to the acquisition or maintenance of materials and equipment, dissemination of results and in other forms of investment.

The majority of the work submitted $(70.4 \%)$ studied the relationship of acupuncture in DTM. According to Gupta et al. ${ }^{21}$, although the therapy may not be useful in the treatment of the disorders, if caused by structural anomalies, such as displacement of the disc and degenerative changes, can help to alleviate the pain and discomfort associated with conditions, especially of muscular origin. It was documented that acupuncture can help in muscle relaxation and reduce muscle spasms, which can result in better conditions and quality of life for patients.

Jung et al. ${ }^{4}$ by means of a systematic review whose objective was to assess the clinical evidence in favor or against the acupuncture and therapies are similar to acupuncture as treatments for the DTM, concluded that the evidence for acupuncture as a symptomatic treatment of TMD is limited and that more rigorous studies are, however, required to establish, with certainty, that acupuncture has therapeutic value for this indication.

Of all the papers on acupuncture presented in the last ten years, only one was a systematic review with meta-analysis. For Galvão and Pereira ${ }^{22}$ this type of study is a randomized study is consistent to try to clarify controversies and contradictory results, since it supports only in studies of better quality on a given subject. It is a type of research focused on an issue which is well defined, which aims to identify, select, assess and summarize the evidence available.

It is important to consider that in spite of the annual meeting of 
the $\mathrm{SBPqO}$ being considered the biggest event of dental research in Brazil, papers on acupuncture in dentistry may have been developed in the country and never presented in congress or sent for more specific congresses, such as complementary therapies, for example. Even so, the annals of $\mathrm{SBPqO}$ served as a good parameter to evaluate the progress of research on acupuncture in dentistry, showing what is being done about the theme in the country in recent years.

\section{Conclusion}

In spite of acupuncture being considered an important complementary therapy in dental practice, considering the results found in this study, it is concluded that few studies about acupuncture in dentistry were developed in the last ten years in Brazil, according to the papers presented at meetings of the SBPqO. Thus, it is suggested that research on the subject be carried out and widely disseminated between the academic and professional milieu.

\section{References}

1. Conselho Federal de Odontologia. Resolução CFO160/2015. Rio de Janeiro: CFO; 2015.

2. Wong LB. Acupuncture in dentistry: Its possible role and application. Proc Singapore Healthc 2012;21(1):48-56. doi: $10.1177 / 201010581202100108$

3. Zotelli VLR, Meirelles MPMR, Sousa M da LR de. Uso da acupuntura no manejo da dor em pacientes com alterações na articulação temporomandibular (ATM). Rev odontol Univ Cid São Paulo 2010;22(2):185-8. doi: 10.26843/ro unicid.v22i2.415

4. Jung A, Shin B-C, Lee MS, Sim H, Ernst E. Acupuncture for treating temporomandibular joint disorders: a systematic review and meta-analysis of randomized, shamcontrolled trials. J Dent 2011;39(5):341-50. doi: 10.1016/j. jdent.2011.02.006

5. Grillo CM, Canales GD la T, Wada RS, Alves MC, Barbosa CMR, Berzin F, et al. Could acupuncture be useful in the treatment of temporomandibular dysfunction? J Acupunct Meridian Stud 2015;8(4):192-9. doi: 10.1016/j. jams.2014.12.001

6. Saito LT, Silvério-Lopes S, Pontes SRB, Suliano LC. Acupuntura sistêmica no tratamento de xerostomia decorrente do uso de anti-hipertensivos: estudo de casos. Rev Bras Terap e Saúde 2012;3(1):9-13. doi: 10.7436/rbts2012.03.01.02

7. Ghazzaoui SF, Romano LTC, Gonnelli FAS, Palma LF. Acupuntura para xerostomia e hipofluxo salivar: revisão de literatura. Rev Bras Odontol 2016;73(4):340-3. doi: 10.18363/rbo.v73n4.p.340

8. Boleta-Ceranto D de CF, Alves T, Alende FL. O efeito da acupuntura no controle da dor na odontologia. Arq Ciênc Saúde Unipar 2008;12(2):143-8.
9. Grillo CM, Wada RS, Sousa M da LR de. Acupuncture in the management of acute dental pain. J Acupunct Meridian Stud 2014;7(2):65-70. doi: 10.1016/j.jams.2013.03.005

10. Florian MR, Rando-Meirelles MPM, Sousa M da LR de. Uso da acupuntura em um caso de parestesia dos nervos alveolar inferior e lingual. Rev Assoc Paul Cir Dent 2012;66(4):3125 .

11. Sant'Anna CBM, Zuim PRJ, Brandini DA, Guiotti AM, Vieira JB, Turcio KHL. Effect of Acupuncture on Post-implant Paresthesia. Acupunct Meridian Stud 2017;10(2):131-4. doi: 10.1016/j.jams.2017.01.004

12. Sardella A, Lodi G, Tarozzi M, Varoni E, Franchini R, Carrassi A. Acupuncture and burning mouth syndrome: a pilot study. Pain Pract 2013;13(8):627-32. doi: 10.1111/ papr. 12031

13. Rosted P, Bundgaard M, Gordon S, Pedersen AML. Acupuncture in the management of anxiety related to dental treatment: a case series. Acupunct Med 2010;28(1):3-5. doi: 10.1136/aim.2009.001933

14. Michalek-Sauberer A, Gusenleitner E, Gleiss A, Tepper G, Deusch E. Auricular acupuncture effectively reduces state anxiety before dental treatment: a randomised controlled trial. Clin Oral Investig 2012;16(6):1517-22. doi: 10.1007/ s00784-011-0662-4

15. Thayer MLT. The use of acupuncture in dentistry. Dent Update 2007;34(4):244-50. doi: 10.12968/denu.2007.34.4.244

16. Gupta D, Dalai DR, Swapnadeep, Mehta P, B NI, Rastogi $\mathrm{S}$, et al. Acupuncture (Zhēn Jiǔ): an emerging adjunct in routine oral care. J Tradit Complement Med 2014;4(4):21823. doi: $10.4103 / 2225-4110.139113$

17. Rosted P. The use of acupuncture in dentistry: a review of the scientific validity of published papers. Oral Dis 1998;4(2):100-4. doi: 10.1111/j.1601-0825.1998.tb00265.x

18. Naik PN, Kiran RA, Yalamanchal S, Kumar VA, Goli S, Vashist N. Acupuncture: an alternative therapy in dentistry and its possible applications. Med Acupunct 2014;26(6):30814. doi: 10.1089/acu.2014.1028

19. Vianna R dos S, Souza AG, Silva BC, Berlinck TÁ, Dias KRHC. A acupuntura e sua aplicação na odontologia. UFES Rev Odontol 2008;10(4):48-52.

20. Conselho Federal de Odontologia. Quantidade geral de cirurgiões-dentistas especialistas. 2019. [acesso em 21 abr 2019]. Disponível em http://cfo.org.br/website/estatisticas/ quantidade-geral-de-cirurgioes-dentistas-especialistas/

21. Gupta D, Somasundaram, Kumaran NS, Batra N, Sandirwal KK, Mahajan S, et al. Acupuncture and dentistry. OHDM 2014;13(4):902-10.

22. Galvão TF, Pereira MG. Revisões sistemáticas da literatura: passos para sua elaboração. Epidemiol e Serviços Saúde 2014;23(1):183-4. doi: 10.5123/S167949742014000100018 